\title{
STOCK MARKET LINKAGES: EVIDENCE FROM THE US, CHINA AND INDIA DURING THE SUBPRIME CRISIS
}

\author{
Amanjot SINGH 1 \\ Parneet KAUR ${ }^{2}$
}

DOI: 10.1515/tjeb-2015-0012

\begin{abstract}
The Subprime crisis spillovered the returns and volatility from the US stock market to the other integrated economies. The present study attempts to analyze the stock market linkages between the US, India and China, especially during the US subprime Crisis. The technique of Tri-Variate Vector Autoregression and the Spillover Index has been employed so as to analyze the relations during the time period 2007 to 2009. To estimate the time varying risk parameters, the technique of Threshold Generalized Autoregressive Conditional Heteroskedastic [TGARCH $(1,1)]$ model has been used. A uni-directional causality has been observed from the US market to the Indian and Chinese market, whereas another unidirectional causality has also been spotted running from the Chinese market to the Indian market in the context of stock market returns during the crisis period. A unidirectional volatility spillover from the US to the Indian market and from the Indian to the Chinese market has been found to be significant. As per the volatility Spillover Index, the cross market impact on the volatility reduces over a time period 2007-2009, due to the increased impact of the past volatility and the presence of 'leverage effect'. The falling returns added to the volatility in the respective markets. The efficient tests of causality inspired by Hill (2007) reported an indirect impact of the US market volatility on the Chinese market via Indian. The portfolio managers should discount this information well ahead of time to maintain the portfolio values by taking positions in futures and options market.
\end{abstract}

Keywords:

Financial Crisis; Spillover; Variance Decomposition; Vector Autoregression Model; Volatility.

JEL Classification: G01, G15, F00, F36.

\footnotetext{
${ }^{1}$ Research Scholar, Punjabi University, India.

${ }^{2}$ Assistant Professor, Punjabi University, India.
} 
Singh, A. \& Kaur, P. (2015).

Stock Market Linkages: Evidence From the US, China and India During the Subprime Crisis

\section{Introduction}

The bursting of the housing sector bubble triggered the subprime crisis in the US, which was not limited only to the banking sector, but also had an impact on the overall financial sector in the US. Moreover, being the dominant economy and increased integration in the context of trade and financial channels with the other different countries, the crisis started in the US gets transferred to the other countries as well, (Angkinand et al., 2009). Even emerging markets like the BRIC nations felt the heat of the crisis due to their increasing exposure to the developed as well as other nations (Beirne et al., 2009). The globalization and the increased integration of the financial system have made the world economies into 'one single market' under which the macroeconomic challenges in one country have an impact on the other countries as well, making way for the stock markets in the recipient economies to witness an uneasy phase. When there are fundamental challenges like twin deficit crisis, lower GDP growth rate, unemployment, lower consumer confidence, lesser productivity etc., then that do affect the other integrated economies with which the source country is having the trade and financial relations. However, most of the times it has been observed that the herding behavior of the investors put the stock markets in a tizzy phase especially in developing nations (Laih \& Liau, 2013). So, both the fundamental changes and behavioral finance (investment) catalyse as the spillover agents. Furthermore, the inter linkages among the markets gets strengthened during a crisis period, as studied by Yang et al. (2003) while studying the Asian financial crisis. The fund managers/ investors should discount the linkages among the markets concerned as this would have an impact on the portfolio diversification strategies especially during an adverse event.

How the linkages among the US, Indian and Chinese stock markets pan out during the subprime crisis? And does the lagged returns in the US had an impact on the stock markets of the China and India? Or the other way around. Similarly, does the volatility in the US market had an impact on the volatility in the Indian and Chinese markets?. The present study attempts to model the stock market linkages i.e. the first moment (returns) as well as the second moment (volatility) between the US, India and China during the Subprime crisis and answers the questions that has been raised, by employing Vector Autoregression (VAR) Model. To estimate the conditional variance, Threshold Generalized Autoregressive Conditional Hetroskedastic Model [TGARCH $(1,1)]$ model has been used. The period considered for the purpose of study ranges from 2007 to 2009. A case of two promising emerging markets (India and China) and one developed market (United States; eventually the source of Global Financial Crisis) has been taken. Moreover, there are differences in the timings of stock markets of the countries concerned: a VAR model with lags as endogenous variables would solve this problem in accounting for spillovers. There are numerous studies that have tried to capture the stock market linkages between the US, Indian and Chinese markets during the subprime crisis (see for details like; Nikkinen et al., 2013; Bianconi et al., 2013; and many more.). But most of the studies have

\section{DE GRUYTER OPEN}

Timisoara Journal of Economics and Business | ISSN: 2286-0991 | www.tjeb.ro Year 2015 | Volume 8 | Issue 1 | Pages: $137-162$ 
Singh, A. \& Kaur, P. (2015).

Stock Market Linkages: Evidence From the US, China and India During the Subprime Crisis

taken a very long period ranging from six to eight years to capture the linkages. However, the present study has tried to account for the linkages during the period 2007-2009, when the major events took place in the US market in relation to the subprime crisis embodying Lehman Brother Crisis, etc. As per the Business Cycle Dating Committee of the National Bureau of Economic Research (2010), the recovery from the US crisis started from June 2009 so the period up till December 2009 has been considered thereby taking the time period comprising of a trough. Apart from the stock market linkages, the study also made an attempt to capture the return and volatility spillovers in an index among the countries concerned; inspired by the methodology adopted by Diebold and Yilmaz (2009).

The Global Competitiveness Report 2013-2014 published by World Economic Forum has recently placed China ahead of the other BRICS nations. China and India are slowly opening up their financial market and other markets as well for the foreign players. Gupta and Wang (2009) highlighted the estimates of the other researchers where they are projecting a manifold increase in the India-China trade numbers compared to the US-China trade relations during the year 2020. With the increasing trade relations with the other countries and increasing capital flows from the Chinese economy, Rajwade (2014) in his article titled "China's Global Economic Power", reported that the day is not that far when we will be having the Yuan as the future reserve currency being decided by the monetary authorities. The steps taken in the form of incorporating a BRIC bank are further paving the way for this achievement.

Both the China and India are among the strongest emerging markets having a wide base of middle income strata of the society, thereby providing a protection to the demand side of the products and services. The trade relations between the China and India are increasing over a period of time. The increasing trade and financial linkages among the China and India have made the stock markets in these respective nations interlinked with each other, as reported by the results. These linkages further have an impact on the portfolio diversification benefits under which the correlation between the asset classes should be lower in order to enjoy the diversification benefits (Click \& Plummer, 2005). Our motive is to study the linkages among the US, Chinese and Indian stock markets and especially during the subprime crisis. The behavior of the US, Chinese and Indian stock markets during the financial crisis is a lesson to be comprehended by the International investors in their efforts to hedge against downside risks in future. The study would provide an insight to the portfolio diversification strategies to be followed by the managers during a turbulent period.

\section{DE GRUYTER} OPEN Year 2015 | Volume 8 | Issue 1 | Pages: 137 - 162 
Singh, A. \& Kaur, P. (2015).

Stock Market Linkages: Evidence From the US, China and India During the Subprime Crisis

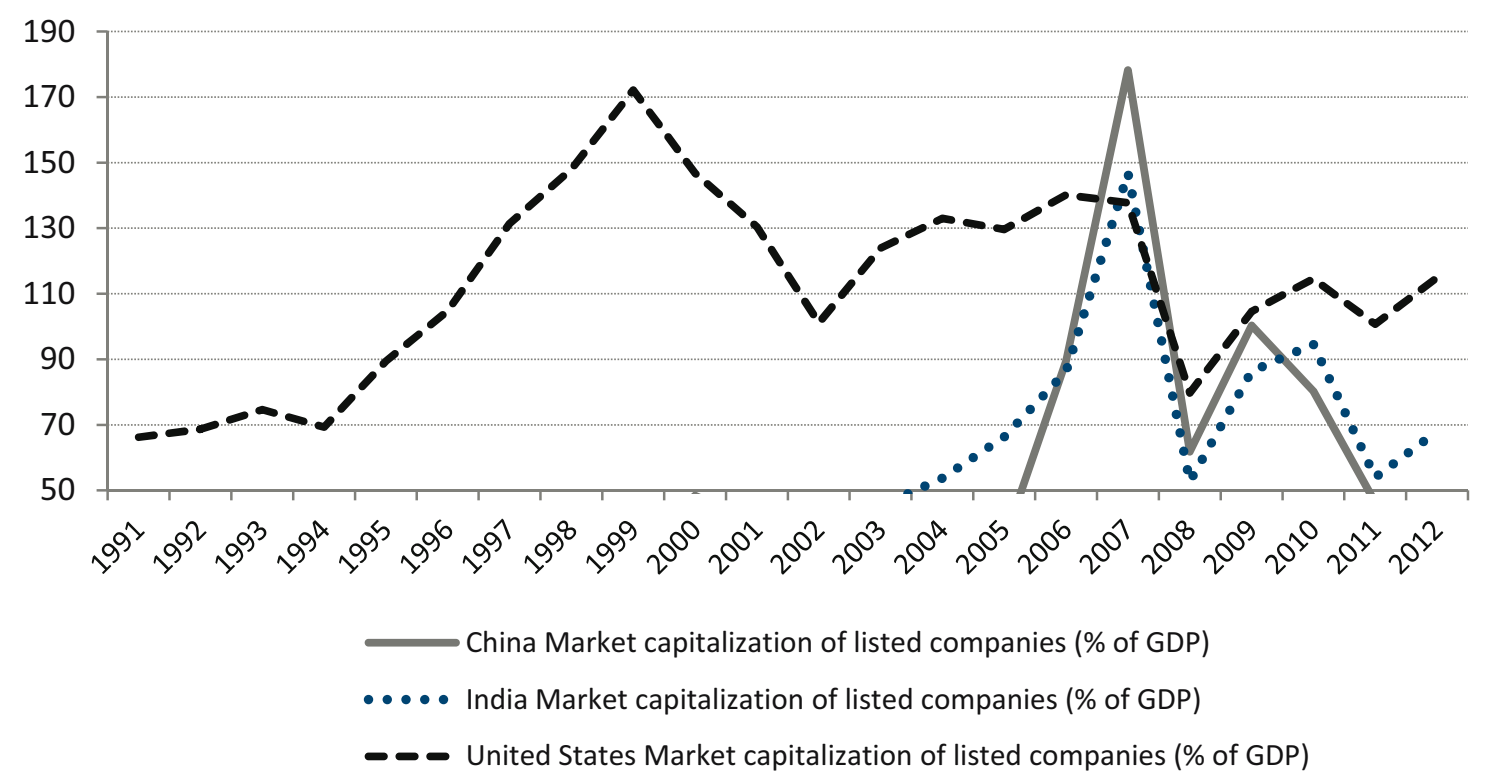

Figure 1. Market Capitalisation \% of GDP

Source: World Bank Data

Figure 1 highlights the market capitalization as a percentage of GDP over a period of time. In the US, the market capitalization has been very high during the period 1999-2000 whereas in India and China it has been high during the period 2007-2008. A very high value (generally above 100) indicates over-valuation of a market. The high market capitalization in China and India during 2007-2008 spotlights the buoyancy in the stock markets before the financial crisis. After this period, a significant decline in the market capitalization as a percentage of GDP can be observed due to the emergence of the crisis during that time period. The decrease in the market capitalization signifies a sharp decline in the stock market due to the emergence of the Subprime crisis. Although most of the countries witnessed this type of a downward rally in their stock markets yet how the markets pan out in terms of the linkages with each other is a question that needs to be answered. The results obtained after employing the VAR model along with the efficiency tests, spotlight the existence of unidirectional spillovers among the countries undertaken during the crisis period. The subprime crisis started in the US acted as a spillover agent in the context of stock market returns and volatility; from the US market to the Indian and Chinese markets.

Our paper contributes to the existing literature in three ways. Firstly, we tried to model the return and volatility linkages among the US, China and India during the actual subprime crisis period 2007-2009, considering a trough phase as well instead of taking a longer period of time. Secondly, we have captured the cross market spillovers in the context of stock market returns and volatility in the form of an index creation. Thirdly, we have employed the VAR model for both

\section{DE GRUYTER OPEN}

Timisoara Journal of Economics and Business | ISSN: 2286-0991 | www.tjeb.ro Year 2015 | Volume 8 | Issue 1 | Pages: $137-162$ 
Singh, A. \& Kaur, P. (2015).

Stock Market Linkages: Evidence From the US, China and India During the Subprime Crisis

the stock market returns and volatility along with Efficient tests proposed by Hill (2007). The results obtained from the TGARCH model have been further modelled into the VAR framework. The rest of the paper has been divided into five sections. Section 2 relates to the review of the literature, sections 3 and 4 comprise the Research Methodology part and the Empirical findings and Interpretation part, respectively. Section 5 concludes the paper.

\section{Literature review}

Over a period of time, many researchers have tried to capture the linkages among the stock markets. The studies are not limited to the stock markets alone, yet the other areas like commodity markets, currency markets and the debt markets have also been taken up by the researchers in order to account for the linkages among them. A rich literature is available on the stock market linkages in this context.

Hamao et al. (1990) examined return spillovers and volatility spillovers in the three major stock markets (New York, Tokyo, and London) by using univariate GARCH models and reported significant volatility and return spillovers among the concerned countries. Friedman and Shachmurove (1997) examined the European Community stock markets by employing a Vector Autoregression (VAR) model. The results showed that the smaller markets, such as Belgium, Denmark and Italy do not have an impact on other markets. The impulse responses reported that Britain is a leading market that have an impact on the France, Netherlands, and Germany. Tabak and lima (2002) examined the causal relationships among the stock markets of Latin America and the United States. The results highlighted that there is some short-run relationship between these stock markets. The Granger causality test detected causality between the Brazilian stock market and other Latin American stock markets. In order to study the dynamic linkages between crude oil price shocks and stock market returns in 22 emerging economies Maghyereh (2004) used Vector Autoregression (VAR) analysis as well. The results supported the evidence that oil shocks have no significant impact on stock index returns in emerging economies.

Click and Plummer (2005) reported that the stock markets of Indonesia, Malaysia, Philippines, Singapore, and Thailand are cointegrated and possess a long run relationship after the Asian financial crisis. The authors also performed certain exclusion tests to see that whether all the variables are present in the long run relation or not. The results showed that all the variables contribute in a significant way in the long run.

While studying the linkages between the two stock exchanges in mainland China, Hong Kong and in the U.S. by employing M-GARCH approach, Li (2007) came out with the finding that the Chinese mainland stock markets have a linkage with the Hong Kong market but have no direct interaction with the U.S. stock market. Valadkhani and Chancharat (2008)

\section{DE GRUYTER OPEN}

Timisoara Journal of Economics and Business | ISSN: 2286-0991 | www.tjeb.ro Year 2015 | Volume 8 | Issue 1 | Pages: 137 - 162 
Singh, A. \& Kaur, P. (2015).

Stock Market Linkages: Evidence From the US, China and India During the Subprime Crisis

investigated cointegration and causality relations between the stock market price indices of Thailand and its major trading partners (Australia, Hong Kong, Indonesia, Japan, Korea, Malaysia, the Philippines, Singapore, Taiwan, the UK and the US). The results of Granger causality reported unidirectional causalities running from the Hong Kong, the Philippines and the UK to Thailand. The authors also found bidirectional Granger causality, between Thailand and three of its neighboring countries (Malaysia, Singapore and Taiwan). Abas (2009) examined the linkages of the two leading emerging markets, i.e. Chinese and Indian market with other developed markets by employing Granger causality and cointegration tests using an error correction model. The author came out with the finding that the Chinese and Indian markets are correlated with all four developed markets undertaken for the purpose of study, United States, United Kingdom, Japan and Hong Kong.

Ismail and Rahman (2009) analyzed the relationship between the US and four Asian emerging stock markets, namely Hong Kong, India, South Korea and Malaysia by employing linear Vector Autoregressive (VAR) model and nonlinear Markov Switching Vector Autoregressive (MS-VAR) model. The results reported that Hong Kong (HSI) and Indian (BSE) markets are significantly affected by the previous one month return of the Korean (KOSPI) market, whereas Malaysia market significantly gets affected by the previous one month return of Hong Kong (HSI) and Korean (KOSPI) markets. Moon and Yu (2010) found an evidence of significant volatility spillover from the US market to the Chinese in the post break period (December 2005) by employing symmetric and asymmetric GARCH-M models. The results are in contrast with Li (2007) because of the time period undertaken for the purpose of study. By making use of various statistical measures Gupta (2011) studied the Co-movement and the direction among the emerging countries, especially the BRIC countries during the condition of financial turmoil. The author finds out that the Indian, Russian and Chinese markets Granger cause Brazilian market. Jeyanthi (2012) examined both the long - run as well as short - run relationships between the stock prices of the BRIC countries by employing Granger Causality test. The Granger causality test reveals that there is bidirectional Granger causality that exists between India and Brazil, India and China for a full sample period and the pre crisis period. Gangadhar and Yoonus (2012) examined the financial integration between the US and the Indian stock market by using Vector Autoregression as well as Cointegration technique. The results found no Co-integration between the two indices, but the Indian returns gets significantly affected by the US returns, whereas Reddy and Wadhwa (2012) explored the financial integration of the BRIC emerging markets and the US market by employing Granger causality test. The results indicate that there is a unidirectional relationship between the US and other stock markets of the BRIC nations. Padhi and Lagesh (2012) employed DCC GARCH model to capture the comovement in volatility in the India, Asian and US market and came out with the finding that bilateral shocks and volatility spillover exists in the India/Malaysia, India/Taiwan and India/Indonesia markets. Singh and Sharma (2012) studied the inter-linkages between the stock markets of Brazil, Russia, India, and China by using the Granger causality model,

\section{DE GRUYTER} OPEN
142
Timisoara Journal of Economics and Business | ISSN: 2286-0991 | www.tjeb.ro Year 2015 | Volume 8 | Issue 1 | Pages: 137 - 162 
Singh, A. \& Kaur, P. (2015).

Stock Market Linkages: Evidence From the US, China and India During the Subprime Crisis

Vector Auto Regression (VAR) model and Variance Decomposition Analysis. The results report that the Russian, Indian and Brazilian stock exchanges affects each other and does gets affected by their own returns excluding the Chinese markets. By employing asymmetric BEKK-GARCH and the VAR approach, Zhang and Jaffry (2015) reported strong bi-directional volatility spillovers during the global financial crisis period between the Mainland China and Hong Kong stock markets.

\section{Research Methodology}

In order to explore linkages among the US, China and India, during the US crisis, stock market indices of the respective countries have been taken into account. The health of an economy can easily be judged based on the equity market of that country. The equity markets are considered to be the riskiest markets compared to the other counterparts and every type of information relating to the economy quickly gets discounted in an equity index (Kumar \& Dhankar, 2009). The indices used are S\&P 500 (US), NIFTY (INDIA) and the Shanghai Composite Index, SSE (CHINA) ranging from January 2007 to December 2009. The daily data have been collected from the website of respective stock exchanges, Yahoo Finance and Wall Street Journal. The CNX NIFTY is a well diversified equity index comprising 50 stocks whereas SSE Composite Index consists of stocks (A shares and B shares) at the Shanghai Stock Exchange. Similarly S\&P 500 contains good quality stocks having strong fundamentals and liquidity. The daily continuously compounded returns (RSANDP, RNIFTY and RSSE) have been calculated for the US, India and China respectively by taking the log of the series.

$$
\mathrm{R}=\log (\mathrm{Pt} / \mathrm{Pt}-1) * 100
$$

Where $\mathrm{R}$ is the daily return, $\mathrm{P}_{\mathrm{t}}$ is the current price and $\mathrm{P}_{\mathrm{t}-1}$ is the previous day price in local currencies. The gaps in the daily prices have been filled up by taking mean of nearby two points. The prices have been taken in their local currencies instead of dollar prices because the local prices would take care of the volatilities in the common currency values.

Going with the literature, the technique of Tri-Variate Vector Autoregression has been employed in order to analyze the dynamic relations between the US, China and Indian markets. The VAR model further consist of three branches to empirically analyze the relations. Out of these three, two branches have been touched, Granger Causality Test/Wald Test and the Variance Decomposition Analysis. To estimate the time varying volatility or conditional variance, TGARCH $(1,1)$ model has been employed. In order to study the return and volatility spillovers among the countries concerned, the technique adopted by Diebold and Yilmaz (2009) has been used along with efficiency tests of causality proposed by Hill (2007).

\section{DE GRUYTER} OPEN
Timisoara Journal of Economics and Business | ISSN: 2286-0991 | www.tjeb.ro Year 2015 | Volume 8 | Issue 1 | Pages: $137-162$ 
Singh, A. \& Kaur, P. (2015).

\subsection{Vector AutoRegression Model}

The methodology of Vector Autoregression has been introduced by Sims (1980). Under Vector Autoregression, as the name suggests, the model consists of the dependent variables which are a function of its own lagged values as well as the lagged values of an another variable plus an error term. Say there are two variables $Y_{1}$ and $Y_{2}$, the mean equations shall be as follows:

$$
\begin{aligned}
& Y_{1, t}=c_{1}+A_{1,1} Y_{1, t-1}+A_{1,2} Y_{2, t-1}+e_{1, t} \\
& Y_{2, t}=c_{2}+A_{2,1} Y_{1, t-1}+A_{2,2} Y_{2, t-1}+e_{2, t}
\end{aligned}
$$

Where $c_{1}$ and $c_{2}$ is a $k \times 1$ vector of constants, $A_{i}$ is a $k \times k$ matrix (for every $i=0, \ldots, p$ ) and $\varepsilon_{t}$ is a $k \times 1$ vector of impulses or shocks. The $\varepsilon_{1}$ and $\varepsilon_{2}$ are the stochastic error terms which are also termed as impulses or innovations or shocks. The lagged values of the dependent as well as the independent variable helps in analysing the dynamic impact of the variables. Under Cholesky Decomposition, the ordering of the variables has been done as per the results reported by the Wald test.

\subsection{TGARCH $(1,1)$ Model}

The TGARCH model, also known as GJR model (Glosten et al., 1993) and an extension of the plain vanilla GARCH $(1,1)$ model, analyses the impact of a negative shock on the volatility or, in short, the 'leverage effect'. Apart from TGARCH, there are various other volatility modelling techniques like EGARCH, Component GARCH, PGARCH, etc. But considering the simplicity of the TGARCH model coupled with as efficient asymmetric results, we have not used the other models. Moreover, the Component GARCH model demarcates the conditional variances into two parts: transitory component (short run) and permanent component (long run). The short time span (2007-2009) has made us to consider only an asymmetric TGARCH model. The model is specified as:

$$
\begin{gathered}
R_{t}=c+\varepsilon_{t} \\
\varepsilon_{t} \sim \operatorname{iid}\left(0, h_{t}\right) \\
h_{t}=\alpha_{0}+\alpha_{1} \varepsilon_{t-1}^{2}+\delta \varepsilon_{t-1}^{2} D_{t-1}+\beta_{1} h_{t-1}
\end{gathered}
$$

where, $D_{t-1}$ is a dummy variable which estimates the leverage effect of a negative shock. If $\varepsilon_{\mathrm{t}-1}<0$, then the value 1 is assigned and otherwise zero. If $\delta$ is found to be significant and positive, then a negative shock has a leverage impact on the conditional variance $\left(\alpha_{1}+\delta\right)$ in comparison to the positive shock, which have an impact equivalent to $\alpha_{1}$ only. $\alpha_{1}$ and $\beta_{1}$ captures the news impact on the conditional variance and the persistency in volatility 
Singh, A. \& Kaur, P. (2015).

Stock Market Linkages: Evidence From the US, China and India During the Subprime Crisis

respectively. The parameters have been estimated by assuming a normal distribution of the error terms coupled with a maximum likelihood approach (Kaur \& Singh, 2015).

\subsection{Cross Market Spillover Index}

Diebold and Yilmaz (2009) came out with a spillover index to calculate the total contribution of the shocks on an asset market arising from the contribution of all other markets. The index is calculated on the basis of $\mathrm{N}$ - variable Vector Autoregression model (Srnic, 2014). The forecasted error variance calculated under the variance decomposition analysis plays a central role in calculating the index values. The variance decomposition analysis reports the contribution of a shock in one variable to the variation in the forecasted error variance of the other variable. The forecasted error variances are splitted into two parts so as to demarcate the own variance shocks and cross market variance shocks. Suppose there are two variables, and the possible spillover shock impacts from the first variable to the second and vice versa are $a_{0,12}^{2}$ and $a_{0,21}^{2}$, respectively. The total of the latter can be regarded as the total spillover impact, whereas the average of the same represents as an Index value, calculated $\mathrm{N}$ step ahead forecasted variances.

\subsection{Efficient Tests Of Causality}

Hill (2007) came out with an recursive parametric representation test procedure for the investigation of multi-steps ahead causation in a trivariate VAR framework (say, $X, Y$ and an auxiliary variable $Z$ ), placing a strong reliance on causality chains (Salamaliki \& Venetis, 2013). The tests help in figuring out the impact of one variable on another as 'Direct' or 'Indirect through an auxiliary variable' and long run versus short run impact. We are trying to model the direct and indirect impact only as the time period under consideration is of shorter duration. The indirect part of the causality states that there might not be a direct impact of $Y$ on $X$ yet there can be an indirect impact through an auxiliary variable ' $Z$ '; $Y$ causes $Z$ and further $Z$ causes $X$. We have conducted efficient, non-causality tests to check the impact of Indian, Chinese and the US markets on each other during the crisis period, inspired by Hill (2007) strategy.

The causality chain is based on three sequential steps. At the very outset, we test for two null hypothesis: $Y$ does not cause $(X$ and $Z$ ) at one step ahead and similarly ( $Y$ and $Z$ ) does not cause $X$ at one step ahead.

$$
\begin{array}{ll}
H_{0}^{(\infty)}=Y^{1} \nrightarrow(X, Z) & \text { Test } 0.1 \\
H_{0}^{(\infty)}=(Y, Z)^{1} \nrightarrow X & \text { Test } 0.2
\end{array}
$$

\section{DE GRUYTER OPEN}

Timisoara Journal of Economics and Business | ISSN: 2286-0991 | www.tjeb.ro Year 2015 | Volume 8 | Issue 1 | Pages: $137-162$ 
Singh, A. \& Kaur, P. (2015).

Stock Market Linkages: Evidence From the US, China and India During the Subprime Crisis

If both the hypothesis are rejected then the test is performed at specific horizons in the second step:

$$
H_{0}^{(1)}=Y^{1} \nrightarrow X \quad \text { Test } 1.0
$$

If we observe a non-causality (Test 1.0), then we proceed to the following tests as a subpart of the second step.

$$
\begin{array}{ll}
H_{0}^{(1.1)}=Y^{1} \nrightarrow Z & \text { Test } 1.1 \\
H_{0}^{(1.2)}=Z^{1} \nrightarrow X & \text { Test } 1.2
\end{array}
$$

If there is a break in the hypothesis (Test 1.1 and Test 1.2), then we assume that $Y$ does not cause $X$. If both are rejected then we proceed to step three. In the third and last step the tests are performed at multiple horizons. For the purpose of calculations, we have taken a fixed rolling window of ' $n$ ' days in the context of stock market returns and volatility in such a way that initially there are at least 21 trading days left till the sample closing date.

\section{Data Analysis and Interpretation}

First of all, an attempt has been made to understand the characteristics/properties of the return series and graphical presentation of the return series. The Table 1 below spotlights the Mean, Median, Standard deviation, etc. of the return series over a period of time. Figure 2 exhibits that the logged returns are volatile throughout the period undertaken into consideration.

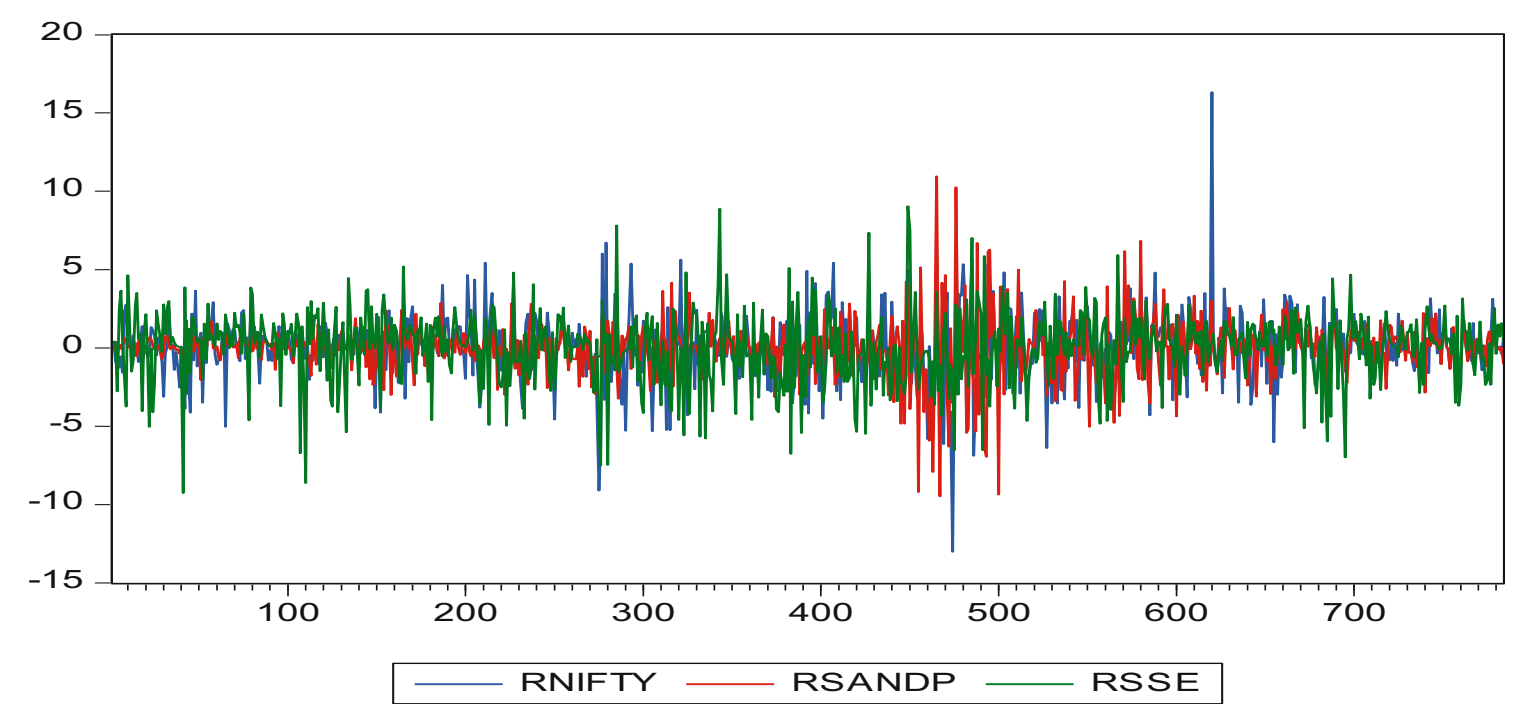

DE GRUYTER OPEN
Timisoara Journal of Economics and Business | ISSN: 2286-0991 | www.tjeb.ro Year 2015 | Volume 8 | Issue 1 | Pages: 137 - 162 
Singh, A. \& Kaur, P. (2015).

Stock Market Linkages: Evidence From the US, China and India During the Subprime Crisis

Figure 2. Graphical presentation of the Stock market returns

Source: Computed by Authors

As one could notice, small changes are followed by smaller changes and the large changes are followed by larger changes, making a case for the application of the GARCH-type models to account for the heteroskedasticity in the error terms. During the crisis period, the average daily returns for the US market are found to be negative, whereas positive returns have been witnessed by both the Indian and Chinese markets coupled with a higher standard deviation as compared to the US. The Jarque-Bera test indicates that the return series are not normally distributed perhaps leptokurtic as the Kurtosis values are greater than three, with respect to each country. Whereas a positive skewness value of NIFTY return series indicates a higher probability of positive returns in comparison to the negative returns.

Table 1. Descriptive statistics: Market Returns

\begin{tabular}{lccc}
\hline \multicolumn{1}{c}{ Year } & RNIFTY & RSANDP & RSSE \\
\hline Mean & 0.03 & -0.03 & 0.02 \\
Median & 0.09 & 0.08 & 0.29 \\
Maximum & 16.33 & 10.96 & 9.03 \\
Minimum & -13.01 & -9.47 & -9.26 \\
Standard Deviation & 2.14 & 1.84 & 2.27 \\
Skewness & 0.08 & -0.15 & -0.34 \\
Kurtosis & 9.56 & 9.55 & 4.67 \\
Jarque-Bera & 1406.26 & 1403.16 & 105.84 \\
Probability & 0.00 & 0.00 & 0.00 \\
\hline
\end{tabular}

Source: Authors' calculations

The skewness values are negative for the US and Chinese markets, indicating a higher probability of negative returns. Overall by looking at the average numbers, we can say that, due to the crisis, US returns have been negative and the flight of capital towards profitable opportunities entailed to higher average returns for the Indian and Chinese markets.

Figure 3 exhibits a 30 days rolling correlation between the S\&P 500 \& NIFTY and S\&P 500 \& SSE; calculated using the computed logged returns. A rolling correlation provides greater information as the time varying coefficients highlight the relationship between the stock market returns of the concerned countries. To calculate the correlation coefficients, the lagged one day return of the US market has been taken instead of the same day return (contemporaneous) because of the differences that exist in the time horizons. The

\section{DE GRUYTER OPEN}

Timisoara Journal of Economics and Business | ISSN: 2286-0991 | www.tjeb.ro Year 2015 | Volume 8 | Issue 1 | Pages: $137-162$ 
Singh, A. \& Kaur, P. (2015).

correlation coefficients remain volatile throughout the period undertaken for the study. During the Lehman Brother crisis, correlation coefficients for both the NIFTY and SSE are very high and positive, thereby depicting a financial integration among the stock markets during that period. Soon after the event, the coefficients headed southward, making the clear case of independency reverting back to the Chinese and Indian stock market returns.

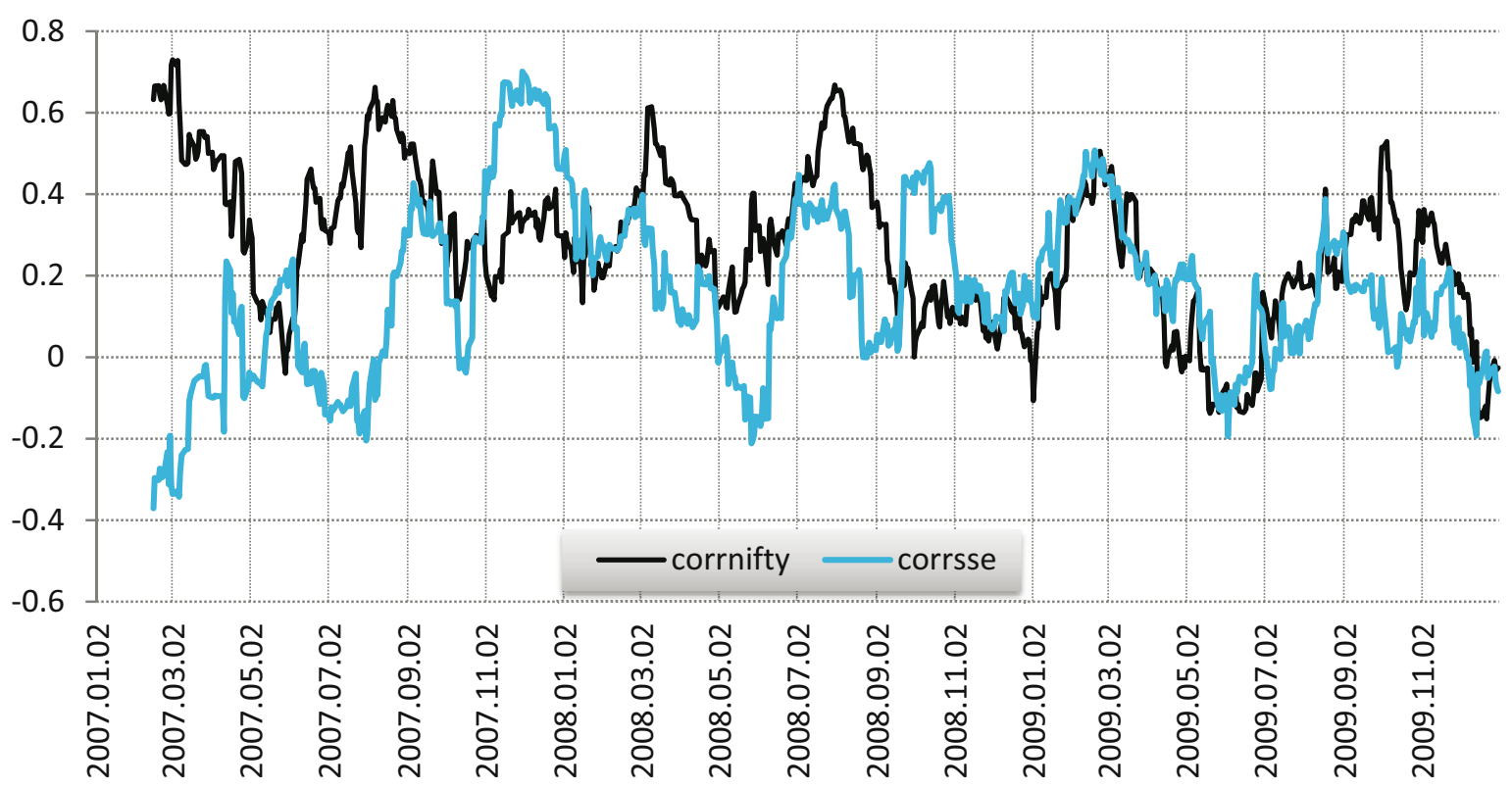

Figure 3. 30 Days Rolling Correlation with the US

Source: Computed by the Authors

The negative correlation provides an opportunity to the global investors to diversify, but the periods of negative or low correlation are followed by the positive correlation that reduces the diversification benefits in the short run.

\subsection{Unit Root Test}

The financial time series data suffers from the problem of the presence of a unit root (see Gujarati et al., 2013). The presence of the unit root can lead to spurious results. The Augmented Dicky-Fuller test has been used in the study to check the presence of a unit root in the series. The Augmented Dickey Fuller test augments the lagged values of the dependent variable in the series:

$$
\Delta Y t=\beta 1+\beta 2 t+\delta Y t-1+\sum_{i=1}^{m} \alpha i \Delta Y t-i+\varepsilon t
$$


Singh, A. \& Kaur, P. (2015).

Stock Market Linkages: Evidence From the US, China and India During the Subprime Crisis

where $\varepsilon_{\mathrm{t}}$ is a pure white noise error term. The null hypothesis is $\delta=0$, where $\delta=p-1$ and the alternate hypothesis is $\delta<0$ (or $p<1$ ). The null hypothesis supports the existence of a unit root in the series, whereas the alternate hypothesis states stationarity or non-existence of a unit root in the series concerned. The return series of the US, Chinese and Indian stock markets are found to be stationary in levels.

The results (see Table 2) support the rejection of null hypothesis which thereby leads to the acceptance of alternate hypotheses stating the stationarity in the return series. Apart from the ADF test, we also resorted to Philips Perron and KPSS test for checking the presence of a unit root in the series. Both the tests showed stationary in the data for each country. Furthermore, to account for a structural break in the series, we employed Zivot and Andrews (1992) test. The test statistic reported stationary series coupled with a structural break. Considering the short time span of 3 years only along with a high frequency data, we ignore the existence of a structural break in the return series of the US, China and India. The VAR model which has been used to capture the linkages requires the financial time series data to be stationary. To check the existence of any stochastic trend between the US, Indian and the Chinese markets, Johansen Cointegration test has also been employed. When any long run or a stochastic trend exists among the variables, then the portfolio diversification benefits get reduced as the markets co-move in the long run. The results generated by the Johansen cointegration approach did not support the existence of any long run relationship between the US, Indian and the Chinese stock markets during the period undertaken for the purpose of study.

Table 2. Unit Root Tests

\begin{tabular}{llll}
\hline \multicolumn{1}{c}{ Test } & $\begin{array}{c}\text { NIFTY } \\
\text { (in levels) }\end{array}$ & $\begin{array}{c}\text { SSE } \\
\text { (in levels) }\end{array}$ & $\begin{array}{c}\text { S\&P } \\
\text { (in levels) }\end{array}$ \\
\hline ADF & $-26.313^{*}$ & $-28.027^{*}$ & $-23.920 *$ \\
Philips Perron & $-26.288^{*}$ & $-28.027 *$ & $-32.158 *$ \\
KPSS & $0.1656 * *$ & $0.3096 *$ & $0.1876 * *$ \\
Zivot-Andrew Test & $-13.261^{*}$ & $-12.081^{*}$ & $-13.070 *$ \\
\hline
\end{tabular}

* Reject Null Hypothesis of Non-stationarity of the series

** Accept Null Hypothesis Of Stationary of Series

Source: Authors' calculations

\subsection{Vector Autoregression Model (Stock Returns)}

After checking and confirming the stationarity of the series, the Tri-Variate Vector Autoregression has been employed. The VAR requires the selection of optimum number of lagged variables to be included. The optimal number of lags (2) has been decided on the basis of Akaike Information Criterion. The results of the VAR model depict the influence of

\section{DE GRUYTER OPEN}

Timisoara Journal of Economics and Business | ISSN: 2286-0991 | www.tjeb.ro Year 2015 | Volume 8 | Issue 1 | Pages: $137-162$ 
Singh, A. \& Kaur, P. (2015).

Stock Market Linkages: Evidence From the US, China and India During the Subprime Crisis

lagged values of the dependent as well as independent variables on the dependent variable. The lagged nature of the VAR model helps in analyzing the dynamic impact of the independent variables on the dependent one.

The lagged values of the NIFTY returns are not statistically significant in influencing NIFTY returns per se, whereas both the US and Chinese market returns statistically influence NIFTY returns. The Chinese stock market returns had a negative impact on the Indian market returns as the coefficient of the one day lagged variable is found to be negative. In case of the US market returns, both the NIFTY and SSE are found to be insignificant, but the lagged returns of the US market itself are found to be significant and, as expected, the coefficients are negative for both the one day and two days lagged variables, thereby highlighting the existence of the subprime crisis during that period. In case of the Chinese market, only the one day lagged return in the US market statistically had an impact on the China's stock market returns and the rest of the variables do not have a statistically significant impact. The VAR model employed is found to be stationary, as all the inverse roots lie inside the unit circle.

The results reported by the VAR model spotlight the existence of a crisis and spillover of the returns during that period as the US market is having a significant impact on the emerging markets. In order to explore the direction of spillovers, Wald Test has been performed (see Table 3). The Wald test helps in judging the joint impact of the lagged independent variables on the dependent variable. The results reported by the Wald test indicate the existence of a unidirectional causality running from the US market to the Indian and Chinese market and the results justify the findings of other researchers like Goldstein and Xie (2009) who discussed the impact of the financial crisis on the Asian economies. The coefficients of the lagged US market returns are positive for both the Indian and Chinese markets, which means that the US stock market returns had a positive impact on the Indian and Chinese markets.

Table 3. Wald Test: Stock Returns

\begin{tabular}{ccc}
\hline Dependent Variable & Explanatory Variable & P-values \\
\hline RNIFTY & RSANDP & 0.0000 \\
& RSSE & 0.0068 \\
RSANDP & RNIFTY & 0.1470 \\
& RSSE & 0.4170 \\
RSSE & RNIFTY & 0.4190 \\
& RSANDP & 0.0001 \\
\hline
\end{tabular}

Source: Authors' calculations

\section{DE GRUYTER} OPEN Year 2015 | Volume 8 | Issue 1 | Pages: 137 - 162 
Singh, A. \& Kaur, P. (2015).

Stock Market Linkages: Evidence From the US, China and India During the Subprime Crisis

The positive impact of the US market during the period undertaken for the study, provides an evidence of the changing mindset of the international investors towards profitable emerging markets after the emergence of the crisis. A uni-directional causality has also been observed from the Chinese stock market to the Indian stock market during the crisis period. The crisis, which got triggered in the US due to the subprime lending policies of the US banks, spillovered the returns from the US stock market to the Indian as well as Chinese stock market.

Table 4 report a direct impact of the US stock market return on the Indian and Chinese stock markets at one step ahead during the fixed rolling sample. On a similar note, a direct impact of Chinese stock market returns on the Indian market has also been observed as the $p$-values are found to be significant after employing Test 1.0. The indirect impact of the one market on the other has not been found to be in existence during the crisis period.

Table 4. Efficient Tests of Causality

\begin{tabular}{cccccccc}
\hline \multirow{2}{*}{ A. V. \# } & \multirow{2}{*}{ D. O. C\#\# } & \multicolumn{7}{c}{ Test p-values } & \multicolumn{1}{c}{ Remarks } \\
\cline { 3 - 8 } & & 0.1 & 0.2 & 1.0 & 1.1 & 1.2 & \\
\hline Chinese (SSE) & India $\rightarrow$ US & 0.2539 & -- & -- & -- & -- & 0.0000 \\
& US $\rightarrow$ India & $0.0000^{*}$ & $0.0000^{*}$ & $0.0000^{*}$ & -- & -- & 0.0068 \\
\multirow{2}{*}{ US (S\&P 500) } & China $\rightarrow$ India & $0.0269 *$ & $0.0000^{*}$ & $0.0090^{*}$ & -- & -- & 0.1470 \\
& India $\rightarrow$ China & 0.2539 & -- & -- & -- & -- & 0.4170 \\
Indian (NIFTY) & US $\rightarrow$ China & $0.0000^{*}$ & $0.0000^{*}$ & $0.0001^{*}$ & -- & -- & 0.4190 \\
& China $\rightarrow$ US & $0.0269 *$ & 0.3657 & -- & -- & -- & 0.0001 \\
\hline
\end{tabular}

\# Auxiliary Variable; \#\# Direction Of Causality *Reject null of no causality between the variables.

Source: Authors' calculations.

\subsection{Variance Decomposition Analysis (Stock Returns)}

Under Vector Autoregression framework, the lagged values of both the dependent variable as well as the independent variable are factored into the equation. The lagged nature of the variables carries forward the impact of any shock or an impulse into the other variable. In other words, when a shock is given to the error term of the first variable, then it does have an impact on the second variable as well because of the existence of lagged values of the first variable. Now, how the variables respond when a shock is given to an error term. To capture the responses of the endogenous variables over a period of time, impulse responses are computed. But in the present study we are focusing only on the Variance Decomposition analysis, which states that when a shock (positive or negative) is given to a variable, then that accounts for what percentage of variation in the other variable at the time of forecasting. How much of the variations are being caused by the variable itself and

\section{DE GRUYTER OPEN}

Timisoara Journal of Economics and Business | ISSN: 2286-0991 | www.tjeb.ro Year 2015 | Volume 8 | Issue 1 | Pages: $137-162$ 
Singh, A. \& Kaur, P. (2015).

Stock Market Linkages: Evidence From the US, China and India During the Subprime Crisis

how much of the variations are caused by some other endogenous variable at the time of one period ahead forecasting? The variance decomposition analysis attempts to answer this question by considering certain periods in the near future.

A shock to the US stock market returns caused $99 \%$ of the fluctuations in the US market returns per se throughout 10 periods ahead forecasted error variance (see Table 5). On the tenth day, a shock to the US market returns, contributed around 19\% in forecasted error variance of Indian market whereas the contribution of the Chinese stock market is only $6 \%$. The contribution of the US stock market in the forecasted error variances is lesser compared to our expectation. But the period which we are taking is from the year 2007 to 2009 , when the recovery started taking place in the markets. A shock to both the US and Indian stock markets contributed very less in the forecasted error variance of China's stock market returns.

Table 5. Variance Decomposition

\begin{tabular}{ccccc}
\hline Variable / Period & S.E. & RSANDP & RNIFTY & RSSE \\
\cline { 1 - 3 } RSANDP & 1.812080 & 100.0000 & 0.000000 & 0.000000 \\
\hline 1 & 1.848433 & 99.40698 & 0.486911 & 0.106109 \\
10 & 1.848495 & 99.40672 & 0.486966 & 0.106318 \\
\hline RSANDP & & & \\
\hline 1 & 2.070640 & 13.99227 & 80.80948 & 5.198246 \\
5 & 2.147272 & 18.78694 & 75.30507 & 5.907990 \\
10 & 2.147359 & 18.79308 & 75.29918 & 5.907739 \\
\hline RSANDP & & & & \\
\hline 1 & 2.245715 & 0.533287 & 0.000000 & 99.46671 \\
5 & 2.283309 & 3.560084 & 0.179075 & 96.26084 \\
10 & 2.283317 & 3.560821 & 0.179079 & 96.26010 \\
\hline
\end{tabular}

Source: Authors' calculations

A reason that could be attributed to the lesser contribution of the US and Indian markets in the forecasted error variance of China is that the Chinese economy has still not opened up the financial sector in a much more free manner and the reforms are underway. 
Singh, A. \& Kaur, P. (2015).

Stock Market Linkages: Evidence From the US, China and India During the Subprime Crisis

\subsection{Returns Spillover Index}

The first row of the Table 6 exhibits the contribution of the shocks towards the US market arising from the US market itself then from the Chinese and Indian stock market. Similarly, the second and third row highlights the contribution of the shocks arising from the stock market of the respective countries itself and also from the other countries. A total value of contributions from other markets is taken for the calculation of spillover index. The total value is further divided by the number of variables present in the study to arrive at an index value. Table 6 report the result of the spillover index value for the full sample period taken into consideration, starting from the year 2007 to 2009. The variance decomposition analysis has been performed and the 10 days ahead contribution of the shocks has been taken into account at the time of calculating the index value. The spillover index value is $10 \%$, which states that about $10 \%$ of the variations have been caused by the cross market shocks, whereas, $90 \%$ of the variations have been caused by the own market shocks. The value of the index is an average result of the full sample period for all the markets.

Table 6. Spillover Index*

\begin{tabular}{ccccc}
\hline To & \multicolumn{3}{c}{ From } & $\begin{array}{c}\text { Contribution from } \\
\text { others }\end{array}$ \\
\cline { 2 - 4 } & US & China & India & $1 \%$ \\
US & $99 \%$ & $0 \%$ & $1 \%$ & $4 \%$ \\
India & $4 \%$ & $96 \%$ & $0 \%$ & $25 \%$ \\
Contribution to others & $19 \%$ & $6 \%$ & $75 \%$ & $30 \%$ \\
\hline
\end{tabular}

*Variance decomposition for 10 days ahead based on VAR with two lags and a constant. Spillover index value = $30 \% / 3=10 \%$.

Source: Authors' calculations

The above case was in relation to the full sample period, but to have a deeper insight we have computed the spillover index plot as well. The spillover plot shows the index values over a period of time. The spillover plot has been calculated by taking 50 days window of the financial data (return series) collected like 1-50, 51-100, 101-150 and so on. To estimate the spillover index value, two days ahead forecasted error variance values have been taken into account. Figure 4 exhibits the spillover plot for the Variance decomposition for two days ahead forecasted error variance, based on VAR with two lags and a constant. 
Singh, A. \& Kaur, P. (2015).

Stock Market Linkages: Evidence From the US, China and India During the Subprime Crisis

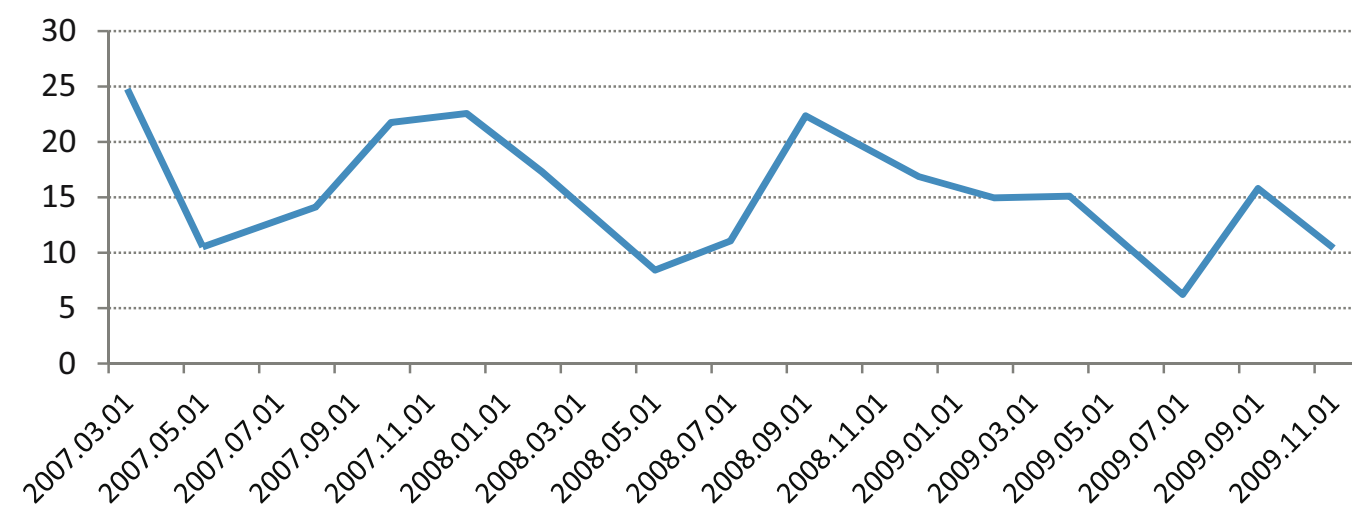

Figure 4. Returns Spillover Plot

Source: Computed by the Authors

The spillover index follows the pattern of sideways throughout the period undertaken for the study. The curve was higher somewhere around the last quarter of the year 2008 when the Lehman Brother episode was telecasted. The higher value of the index during this period signifies the impact of the cross market shocks on the stock market returns of the US, India and China. The impact emanating from the internal markets is higher compared to the cross markets as the study revolves around only three countries. If we increase the span of the countries, the results shall precisely be improved.

\subsection{Estimation of the Conditional Variance}

Table 7 report the results of the TGARCH $(1,1)$ model. In case of the US market, the news effect captured by $\alpha_{1}$ is found to be insignificant at the $5 \%$ level, whereas the impact of the past volatility (0.9309) on the current conditional volatility is significant. The asymmetric coefficient is significant thereby highlighting the asymmetric impact of the positive and negative shocks on the conditional variance, wherein a negative shock increases the volatility. Similarly, in case of the Chinese market, the news impact is not found to be significant. The impact of past volatility and the asymmetric impact has been observed in the case of China as well. The results in the case of Indian market are similar to the US and Chinese markets, barring the news impact on the current conditional variance. A statistically significant impact of one day lagged news component has been found at the $5 \%$ level.

Overall, we can say that the impact of past volatility is higher during the period undertaken. The investors took a larger time to digest the information coming into the markets. The adequacy of the TGARCH $(1,1)$ model has been confirmed by the correlograms of the standardised residuals derived from the variance equation. Figure 5 is the graphical presentation of the conditional variances derived by employing the TGARCH $(1,1)$ model.

\section{DE GRUYTER OPEN}

Timisoara Journal of Economics and Business | ISSN: 2286-0991 | www.tjeb.ro Year 2015 | Volume 8 | Issue 1 | Pages: $137-162$ 
Singh, A. \& Kaur, P. (2015).

Stock Market Linkages: Evidence From the US, China and India During the Subprime Crisis

Table 7. TGARCH $(1,1)$ Results

\begin{tabular}{ccccccc}
\hline \multirow{2}{*}{ To } & \multicolumn{2}{c}{ US } & \multicolumn{2}{c}{ China } & \multicolumn{2}{c}{ India } \\
\cline { 2 - 7 } & Coefficient & Probability & Coefficient & Probability & Coefficient & Probability \\
\hline$\alpha_{1}$ & -0.0198 & 0.2116 & 0.0089 & 0.5759 & 0.0607 & $0.0002 *$ \\
$\beta_{1}$ & 0.9309 & $0.0000 *$ & 0.8427 & $0.0000 *$ & 0.8558 & $0.0000 *$ \\
$\delta$ & 0.1493 & $0.0000 *$ & 0.1394 & $0.0000 *$ & 0.1374 & $0.0000 *$ \\
\hline
\end{tabular}

*Significant at the 5\% level

Source: Authors' calculations

An increased amount of volatility can be seen during the last quarter of the year 2008 (after $450^{\text {th }}$ observation). This volatility has been due to the Lehman Brothers episode that took place during that time period. After estimating the conditional variances, the VAR model has been employed on the conditional variances of the respective countries as well, so as to capture the spillover impact of the volatility.

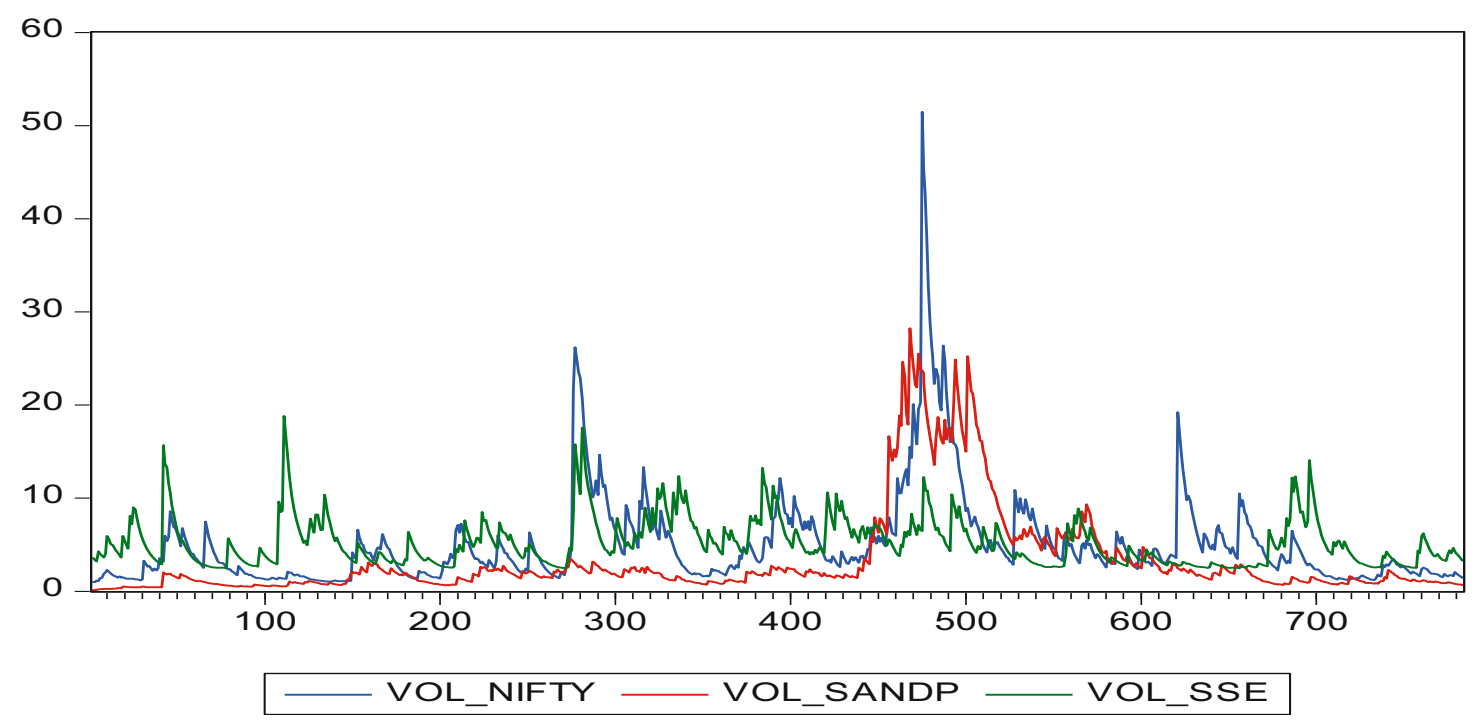

Figure 5. Graphical presentation of the Conditional variances

Source: Computed by Authors

\subsection{Vector Autoregression Model (Stock Volatility)}

The optimal lag length was set to 3 using Akaike Information Criterion lagged values as reported by the AIC criteria are three. A significant impact of the one day lagged volatility in the Indian market, two days and three days lagged volatility in the US market on the Indian market volatility has been observed. The results exhibit inefficiency in the Indian market due to the impact of past two and three days volatility on the Indian markets. The impact of

\section{DE GRUYTER} OPEN 
Singh, A. \& Kaur, P. (2015).

Stock Market Linkages: Evidence From the US, China and India During the Subprime Crisis

two days past volatility in the US market and one day lagged volatility in the Indian market itself increases the volatility in the Indian market, as reported by VAR.

Similarly, in case of the Chinese market, the impact of one day lagged volatility in the Chinese market, one and two days lagged volatility in the Indian market, has been observed on the Chinese market volatility. In case of the US market, the volatility gets influenced by one day and three days lagged volatility in the US market itself, two days and three days lagged volatility in the Indian market. The impact of one day lagged volatility in the Indian market does not have a statistically significant impact on the volatility in the US market, whereas the impact of the one day lagged volatility in the US market itself is positive and massive $(0.8549, p<0.05)$. The VAR model employed is found to be stationary, as all the inverse roots lie inside the unit circle.

Table 8. Wald Test: Stock Volatility

\begin{tabular}{ccc}
\hline Dependent Variable & Explanatory Variable & P-values \\
\hline RNIFTY & RSANDP & $0.0000^{*}$ \\
& RSSE & 0.9637 \\
RSANDP & RNIFTY & 0.0627 \\
& RSSE & 0.7238 \\
RSSE & RNIFTY & $0.0000^{*}$ \\
& RSANDP & 0.5226 \\
\hline
\end{tabular}

* Significant the $5 \%$ level.

Source: Authors' calculations

To analyze the joint impact of the lagged volatilities, Wald test has been used. Table 8 report the results of the lagged volatilities in the respective countries on the current conditional volatility. There is uni-directional volatility running from the US market to the Indian market. A uni-directional volatility has also been observed running from the Indian market to the Chinese market. The volatility in the Indian and the Chinese market do not have a statistically significant impact on the US market volatility.

Table 9, report a direct impact of the US and Indian market on the Chinese market in the context of stock market volatility. Surprisingly, an indirect impact of the US stock market volatility on the Chinese market has been observed taking the Indian stock market volatility as an auxiliary variable. Furthermore, two steps and even seven steps ahead calculations confirm the indirect impact from the US to India and then China during the crisis period. 
Singh, A. \& Kaur, P. (2015).

Stock Market Linkages: Evidence From the US, China and India During the Subprime Crisis

Table 9. Efficient Tests of Causality

\begin{tabular}{|c|c|c|c|c|c|c|c|}
\hline \multirow{2}{*}{ A. V. \# } & \multirow{2}{*}{ D. O. C\#\# } & \multicolumn{5}{|c|}{ Test p-values } & \multirow{2}{*}{ Remarks } \\
\hline & & 0.1 & 0.2 & 1.0 & 1.1 & 1.2 & \\
\hline \multirow[t]{2}{*}{ Chinese (SSE) } & India $\rightarrow$ US & $0.0000 *$ & 0.2512 & -- & -- & -- & \\
\hline & US $\rightarrow$ India & $0.0000 *$ & $0.0000 *$ & $0.0000 *$ & & & Direct \\
\hline \multirow[t]{2}{*}{ US (S\&P 500) } & China $\rightarrow$ India & 0.9554 & -- & -- & -- & -- & \\
\hline & India $\rightarrow$ China & $0.0000^{*}$ & $0.0000 *$ & $0.0000 *$ & -- & -- & Direct \\
\hline \multirow[t]{2}{*}{ Indian (NIFTY) } & US $\rightarrow$ China & $0.0000 *$ & $0.0000 *$ & 0.5371 & $0.0000 *$ & $0.0000 *$ & Indirect \\
\hline & China $\rightarrow$ US & 0.9554 & -- & -- & -- & -- & \\
\hline
\end{tabular}

\# Auxiliary Variable; \#\# Direction Of Causality *Reject null of no causality between the variables.

Source: Authors' calculations.

\subsection{Variance Decomposition Analysis (Stock Volatility)}

After applying the Wald test, Variance decomposition analysis has been performed. When a shock is given to the NIFTY volatility then that accounts for $89 \%$ of the variation in the NIFTY itself on the $10^{\text {th }}$ day ahead forecasted error variance. Table 10 reports the results of the variance Decomposition Analysis.

Table 10. Variance Decomposition

\begin{tabular}{|c|c|c|c|c|}
\hline Variable / Period & \multirow{2}{*}{ S.E. } & \multirow{2}{*}{ VOLNIFTY } & \multirow{2}{*}{ VOLSANDP } & \multirow{2}{*}{ VOLSSE } \\
\hline VOLNIFTY & & & & \\
\hline 1 & 1.732387 & 98.03316 & 1.966841 & 0.000000 \\
\hline 5 & 3.354358 & 93.49602 & 6.490633 & 0.013350 \\
\hline 10 & 3.908953 & 88.65815 & 11.33032 & 0.011536 \\
\hline \multicolumn{5}{|l|}{ VOLSANDP } \\
\hline 1 & 0.904603 & 0.000000 & 100.0000 & 0.000000 \\
\hline 5 & 1.643489 & 0.495439 & 99.36449 & 0.140075 \\
\hline 10 & 2.181560 & 1.056651 & 98.84046 & 0.102893 \\
\hline \multicolumn{5}{|l|}{ VOLSSE } \\
\hline 1 & 1.176779 & 0.897194 & 0.009505 & 99.09330 \\
\hline 5 & 2.089198 & 7.577776 & 0.869837 & 91.55239 \\
\hline 10 & 2.416170 & 8.393609 & 1.143217 & 90.46317 \\
\hline
\end{tabular}

Source: Authors' calculations

\section{DE GRUYTER} OPEN
Year 2015 | Volume 8 | Issue 1 | Pages: 137 - 162 
Singh, A. \& Kaur, P. (2015).

Stock Market Linkages: Evidence From the US, China and India During the Subprime Crisis

The contribution of the volatility in the US market enhanced over a period of time in the forecasted error variance of Indian market. On the other hand, when a shock is given to the volatility in the Indian and the Chinese market, then that contributes very little to the variation in the US market volatility over a period of 10 days. The contribution of the shocks in the Indian market to the variation in the Chinese market increases over a period of 10 days ahead forecasted error variance.

\subsection{Volatility Spillover Index}

Figure 6 exhibits the spillover plot created by Variance decomposition for two days ahead forecasted error variance, based on VAR with three lags and a constant. The Index values reduced over a period of time (2007-2009). The impact of cross market volatility has reduced from the highest point of 46 to the lowest 17 .

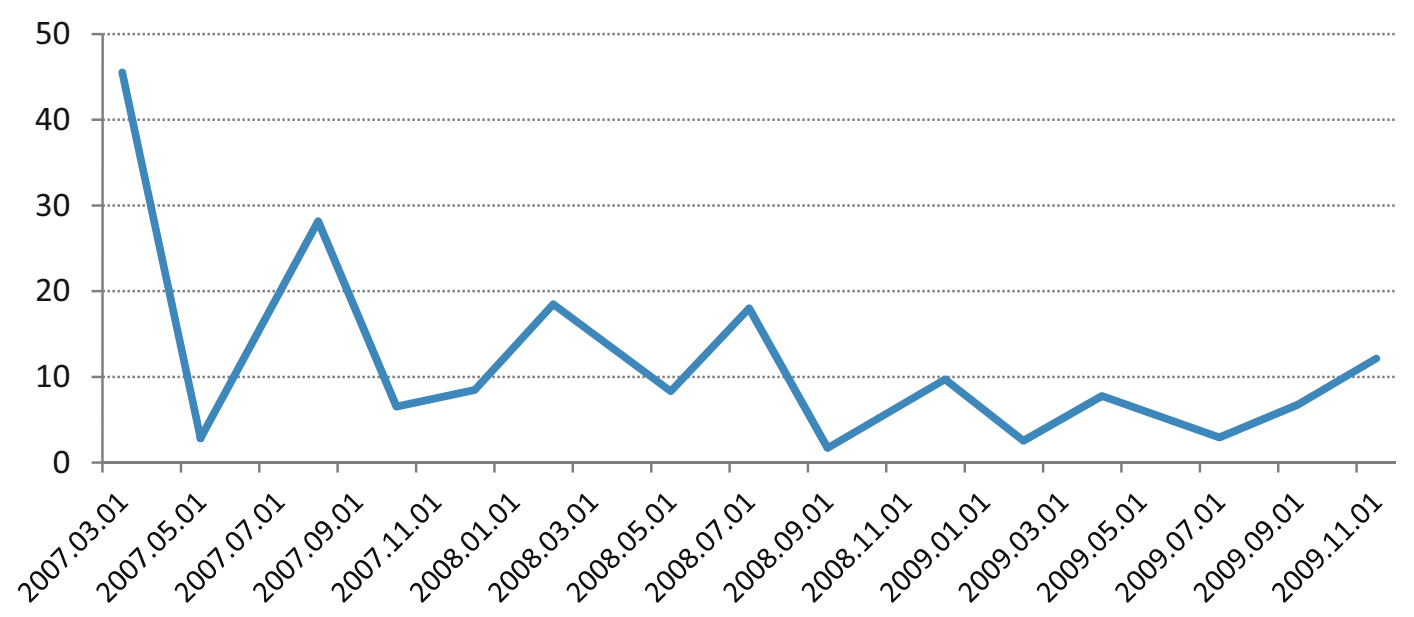

Figure 6. Volatility Spillover Plot

Source: Computed by Authors

The results reported by the TGARCH $(1,1)$ model confirm the spillover Index pattern. Since, there is an impact of the past volatility in the respective countries on the current conditional variances, the spillover index exhibits a reducing impact of the cross market shocks on the forecasted error variance. The past volatility present in the market and leverage effect had an impact on the current variations rather than the cross market impact. The information transmissions that took place at the start of the crisis in the countries concerned remained in the mind of the investors all through the time period undertaken.

To summarize the findings, there is a uni-directional spillover from the US market to the Indian and Chinese market in the context of the stock market returns, as reported by most of the studies. Kharchenko nd Tzvetkov (2013) came out with the findings that after the

\section{DE GRUYTER OPEN}

Timisoara Journal of Economics and Business | ISSN: 2286-0991 | www.tjeb.ro Year 2015 | Volume 8 | Issue 1 | Pages: $137-162$ 
Singh, A. \& Kaur, P. (2015).

emergence of the crisis, the impact of the volatility was from the developed markets to the Indian market, whereas our results reported the impact of lagged volatility in the Indian market on the US market volatility as well during the period undertaken. Considering the stock market volatility, there is a uni-directional spillover from the US market to the Indian market only and from the Indian market to the Chinese market. Over a period of time, cross market impact on the forecasted error variance of the market volatility reduces highlighting the impact of past volatility in the market.

\section{Concluding Remarks}

To explore linkages among the US, China and India, during the US crisis, stock market indices, of the respective countries have been taken and the technique of Tri-Variate Vector Autoregression has been employed so as to analyze the relations. The results support that lagged values of the NIFTY returns are not statistically significant in influencing NIFTY returns, whereas both the Chinese and US markets statistically influence NIFTY returns. A unidirectional causality has been observed from the US and Chinese markets to the Indian market in the context of market returns during the crisis period with a negative impact of the Chinese returns. Considering the stock market volatility, there is a uni-directional spillover from the US market to the Indian market only and from the Indian market to the Chinese market. There is a significant impact of the lagged volatility in the Indian market on the US market. The cross market impact reduces over a period of time signifying the impact of past volatility on the current conditional variance. Surprisingly, the efficient tests of causality came out with the finding that there is an indirect impact of the US stock market volatility on the Chinese market volatility via Indian Market. The study of these linkages is an imperative task to be performed by the international portfolio managers. The managers should discount this type of information well ahead of time so as to hedge themselves from any adverse situation arising due to any crisis or a country specific event. The past events always act as a catalyst in guiding the future trends. The behavior of the US, Chinese and Indian stock markets during the financial crisis is a lesson to be comprehended by the International investors in their efforts to hedge against downside risks in future. The causal relations have an impact on the co-movement of the markets, thereby entailing to portfolio adjustments in the countries concerned.

\section{Acknowledgement:}

We would like to express our gratitude towards reviewer(s) of the paper for giving enormously useful suggestions. The mistakes, if any, are our responsibility.

\section{DE GRUYTER OPEN}

Timisoara Journal of Economics and Business | ISSN: 2286-0991 | www.tjeb.ro Year 2015 | Volume 8 | Issue 1 | Pages: $137-162$ 
Singh, A. \& Kaur, P. (2015).

\section{References}

Abas, M. (2009). Analysis of Stock Market Linkages: Chinese, Indian and Major Markets. University of Malaya Report, pp: 1-94.

Angkinand, A. P., Barth, J. R., \& Kim, H. (2009). Spillover Effects from the U.S. Financial Crisis: Some Time-Series Evidence from National Stock Returns. In The Financial and Economic Crises: An International Perspective, ed. Benton, E. G., 24-52. Cheltenham: Edward Elgar Publishing.

Beirne, J., Caporale, G. M., Schulze-Ghattas, M., \& Spagnolo, N. (2009). Volatility Spillovers and Contagion from Mature to Emerging Stock Markets. European Central Bank, Working Paper Series No. 1113.

Bianconi, M., Yoshino, J. A., \& Sousa, M. O. (2013). BRIC and the U.S. Financial Crisis: An Empirical Investigation of Stock and Bond Markets. Emerging Markets Review, 14, 76-109.

Click, R., \& Plummer, M. (2005). Stock Market Integration in ASEAN after the Asian Financial Crisis. Journal of Asian Economics, 16(1), 5-28.

Diebold, F. X., \& Yilmaz, K. (2009). Measuring Financial Asset Return and Volatility Spillovers, with Application to Global Equity Markets. The Economic Journal, 119, 158-71.

Friedman, J., \& Shachmurove, Y. (1997). Using Vector Autoregression Models to Analyze the Behavior of the European Community Stock Markets. CARESS Working Paper 97-04.

Gangadharan, S. R., \& Yoonus, C. (2012). Global Financial Crisis and Stock Market Integration: A Study on the Impact of the Global Financial Crisis on the Level of Financial Integration between the US and Indian Stock Market. Asia-Pacific Journal of Management Research and Innovation, 8, 101-110.

Glosten, L., R., Jagannathan R., \& Runkle, D. (1993). On the Relation between Expected Value and the Volatility of the Nominal Excess Return on Stocks. Journal of Finance, 48 (5), 1779-1801.

Goldstein, M., \& Xie, D. (2009). The Impact of the Financial Crisis on Emerging Asia. Peterson Institute for International Economics, Working Paper Series, WP09-11.

Gujarati, D., Porter, D., \& Gunasekar, S. (2013). Basic Econometrics. New Delhi: McGraw Hill Education (India) Private Limited.

Gupta, A., \& Wang, H. (2009). China and India: Greater Economic Integration. China Business Review-The magazine of the US-China Business Council. Retrieved from http://www.chinabusinessreview.com/china-and-india-greater-economicintegration

Gupta, S. (2011). Study of BRIC Countries in the Financial Turmoil. International Affairs and Global Strategy, 1, 1-15.

Hamao Y., Masulis R., \& Ng, V. (1990). Correlations in Price Changes and Volatility across International Stock Markets. The Review of Financial Studies, 3(3), 281-307.

Hill, J. B. (2007). Efficient Tests of Long-Run Causation in Tri-Variate VAR Processes with a Rolling Window Study of the Money-Income Relationship. Journal of Applied Econometrics, 22(4), 747-765.

Ismail, M. T., \& Rahman, R. A. (2009). Modelling the Relationships between US and Selected Asian Stock Markets. World Applied Sciences Journal, 7(11), 1412-1418.

Jeyanthi, B. J. (2012). Are the BRIC Equity Markets More Interdependent After the Global Financial Crisis? Indiastat.com. Retrieved from http://www.indiastat.com/article/43/jeyanthi/fulltext.pdf 
Singh, A. \& Kaur, P. (2015).

Stock Market Linkages: Evidence From the US, China and India During the Subprime Crisis

Kharchenko, I., \& Tzvetkov, P. (2013). Estimation of Volatilities and Spillover Effects Between Developed and Emerging Market Economies. Department of Economics, Lunds Universitet. Retrieved from http://lup.lub.lu.se/luur/download?func=downloadFile\&recordOId=3801343 \&fileOld $=3813321$

Kaur, P., \& Singh, A. (2015). Investigating the Leverage Effect and Volatility in the BRIC Countries' Equity Markets After the U.S. Financial Crisis. The Journal of Wealth Management, 17(4), 93-100.

Kumar, R. \& Dhankar, R. S. (2009). Asymmetric Volatility and Cross Correlations in Stock Returns under Risk and Uncertainty. Vikalpa, 34(4), 25-36.

Laih, Y.-W., \& Liau, Y.-S. (2013). Herding Behavior during the Subprime Mortgage Crisis: Evidence from Six Asia-Pacific Stock Markets. International Journal of Economics and Finance, 5(7), 71-84.

$\mathrm{Li}, \mathrm{H}$. (2007). International Linkages of the Chinese Stock Exchanges: A Multivariate GARCH Analysis. Applied Financial Economics, 17(4), 285-297.

Maghyereh, A. (2004). Oil Price Shocks and Emerging Stock Markets: A Generalized VAR Approach. International Journal of Applied Econometrics and Quantitative Studies, 1(2), 27-40.

Moon, G. H., \& Yu, W. C. (2010). Volatility Spillovers between the US and China Stock Markets: Structural Break Test with Symmetric and Asymmetric GARCH Approaches. Global Economic Review: Perspectives on East Asian Economies and Industries, 39(2), 129-149.

National Bureau of Economic Research. (2010, September 20). Business Cycle Dating Committee. Retrieved from http://www.nber.org/cycles/sept2010.html.

Nikkinen, J., Saleem, K., \& Martikainen, M. (2013). Transmission Of The Subprime Crisis: Evidence From Industrial And Financial Sectors of BRIC countries. The Journal of Applied Business Research, 29 (5), 1469-1478.

Padhi, P., \& Lagesh, M. A. (2012). Volatility Spillover and Time-Varying Correlation among the Indian, Asian and US Stock Markets. Journal of Quantitative Economics, 10(2), 78-90.

Rajwade, A. V. (2014). China's Global Economic Power, Yuan as a Future Reserve Currency. Economic and Political Weekly, XLIX(50), 13-16.

Reddy, S.S. \& Wadhwa, K. (2012). International Stock Market Integration: A Study of the US and the BRIC Markets. Research Journal of Economics and Business Studies, 1(3), 56-67.

Salamaliki, P. K., \& Venetis, I. A. (2013). Efficient Tests of Long-Run Causation in Trivariate VAR Processes with a Rolling Window Study of the Money-Income Relationship. Energy Economics, 39, 108-121.

Sims, C. (1980). Macroeconomics and Reality. Econometrica, 48, 1-48.

Singh, S., \& Sharma, G. D. (2012). Inter-Linkages between Stock Exchanges: A Study of BRIC Nations. International Journal of Marketing, Financial Services \& Management Research, 1(3), 1-17.

Srnic, B. S. (2014). Impact of Economic Crisis Announcements on BRIC Market Volatility. Faculty of Social sciences, Charles University in Prague. Retrieved from https://is.cuni.cz/webapps/zzp/download/120166581

Tabak, B. M., \& Lima, E. J. (2002). Causality and Cointegration in Stock Markets: The Case of Latin America. Central Bank of Brazil, Research Department. Retrieved from http://www.bcb.gov.br/pec/wps/ingl/wps56.pdf 
Singh, A. \& Kaur, P. (2015).

Stock Market Linkages: Evidence From the US, China and India During the Subprime Crisis

Valadkhani, A., \& Chancharat, S. (2008). Dynamic Llinkages between Thai and International Stock Markets, Journal of Economic Studies, 35(5), 425-441.

Yang, J., Kolari, J. W., \& Min, I. (2003). Stock Market Integration and Financial Crises: the Case of Asia. Applied Financial Economics, 13(7), 477-486.

Zhang, Q., \& Jaffry, S. (2015). Global Financial Crisis Effects on Volatility Spillover between Mainland China and Hong Kong Stock Markets. Investment Management and Financial Innovations, 12(1), 26-34.

Zivot, E., \& Andrews, K. (1992). Further Evidence On The Great Crash, The Oil Price Shock, and The Unit Root Hypothesis. Journal of Business and Economic Statistics, 10(10), 251-70. 